Jurnal Teknologi Laboratorium

Vol.9, No.1, June 2020, pp. $121-127$

ISSN 2580-0191(Online), ISSN 2338 - 5634(Print)

DOI: $10.29238 /$ teknolabjournal.v9i1.200

Journal homepage: https://www.teknolabjournal.com/index.php/Jtt/index

Original Research

\title{
The potential of traditional balinese spices against the growth of Salmonella sp in vitro
}

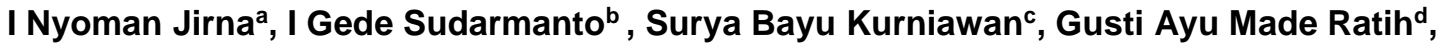 Burhannuddin Rasyide}

Department of Medical Laboratory Technology, Poltekkes Kemenkes Denpasar, Indonesia

a Email address: nyomanjirna@ymail.com

bEmail address: igedesudarmanto@yahoo.com

${ }^{c}$ Email address: suryabayu.kurniawan@yahoo.com

d Email address: iga ratihkurada@yahoo.com

e Email address: boerhannuddin@gmail.com

HIGHLIGHTS

Traditional Balinese have antimicrobial potential.

\section{ARTICLE INFO}

\section{Article history}

Received Date: April 02 ${ }^{\text {nd }}, 2020$

Revised Date: May 24 $4^{\text {th }}, 2020$

Accepted Date: June $09^{\text {th }}, 2020$

\section{Keywords}

Traditional Balinese spices

Antimicrobial potential

Salmonella $s p$

\begin{abstract}
A B S T R A C T
Prevention by utilizing medicinal plants can be used as an alternative treatment. This study aims to identify active antimicrobial substances and test the antimicrobial potential of traditional Balinese spices, namely Basa Selem, Basa Gede, Basa Wangen, Basa Bawang Jahe, and Basa Rajang against Salmonella sp bacteria in vitro. The True-experimental method with Posttest only-control design was used in this study, by intervening in the treatment group as well as the presence of positive and negative controls. Maceration method with $96 \% \mathrm{EtOH}$ solvent was used to extract active substances and identify the levels of antimicrobial active substances. The TLC Spectrophotodensitometer instrument and the diffusion method (discs) were used to test antimicrobial potential. Data analysis was performed using the one-way ANOVA test. All five samples showed flavonoids, alkaloids, tannins and phenols in qualitative tests. Based on quantitative test results of five samples, the highest compound content obtained in Basa Wangen $(6.66 \mathrm{mg} / \mathrm{ml}$ of tannins), Basa Gede (3.74 $\mathrm{mg} / \mathrm{ml}$ of flavonoids), Basa Bawang Jahe $(2.49 \mathrm{mg} / \mathrm{ml}$ of tannins), Basa Selem $(2.87 \mathrm{mg} / \mathrm{ml}$ of tannin), and Basa Rajang $(6.96 \mathrm{mg} / \mathrm{ml}$ of flavonoids). There are differences in the antimicrobial potential of various types of traditional Balinese spices against the growth of Salmonella sp in vitro ( $\mathrm{sig}=0.037$ ). The traditional Balinese spices have the antimicrobial potential of the intermediate category with a range of inhibition (16-20 mm) based on the NCCLS standard.
\end{abstract}

This is an open-access article under the CC-BY-SA license.

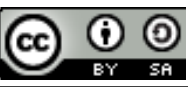

*Corresponding Author:

I Nyoman Jirna

Group Research in Department of Medical Laboratory Technology, Health Polytechnic of Denpasar,

Bali, Indonesia

Email: nyomanjirna@ymail.com

Phone: +62361 710527 


\section{INTRODUCTION}

Indonesia has a diversity of cultures along with the development of various types of food with diverse flavours as well. Spices are often used in various culinary regions in Indonesia as a cooking ingredient. In addition to increasing food flavour, added spices can also increase product durability and also product safety for consumption. Increased shelf life and safety of food products added to spices are caused by the ability of spices to inhibit the growth of bacteria present in food. 1 Many spices are also synergists when combined, and those spices exhibit greater antibacterial effects than when each is used alone.?

Spices are also believed to be beneficial for health because they contain many bioactive compounds that function as antimicrobials, antioxidants, antidiabetic, antitumor, and other functions that are very beneficial for maintaining health. For this reason, spices are widely developed for traditional medicine because they are believed not to cause harmful side effects ${ }^{1}$. The food ingredients made from spices are processed in a simple way. Traditional spices are very beneficial in the absence of chemicals such as monosodium glutamate (MSG), which are commonly used as flavouring ingredients. $\frac{3}{}$ The use of traditional spices which is a collection of various spices in making Balinese sausages (Urutan) functions as a flavouring, preservative, antioxidant and antimicrobial.$\underline{3}$

The content of essential oils in spices can be used to inhibit the growth of bacteria in food. The results of other studies show that spices produce Allicin (the active substance of garlic) can penetrate quickly into different parts of the cell and cause biological effects. ${ }^{1}$ Other ingredients that are often used in traditional herbs are garlic, mustard, cloves and ginger. Cloves have the highest antibacterial activity followed by garlic, while mustard and ginger show smaller antibacterial activity. 1 The spices are also found in traditional Balinese spices such as Basa Wangen, Basa Gede, Basa Bawang Jahe, Basa Selem, and Basa Rajang. This research was conducted to study the antimicrobial potential of traditional Balinese spices against the growth of Salmonella sp in vitro.

\section{MATERIAL AND METHOD}

There are five types of traditional Balinese spices such as Basa Wangen, Basa Gede, Basa Bawang Jahe, Basa Selem, and Basa Rajang. The total number of samples from this study was 56 samples, where there were eight times replications from 5 treatment groups with one positive control and one negative control ${ }^{4}$. Antimicrobial potential was evaluated by measuring inhibition zone diameters, using $96 \% \mathrm{EtOH}$ as a negative control and Ciprofloxacin $5 \mu \mathrm{g}$ as a positive control. Maceration method with $96 \% \mathrm{EtOH}$ solvent was used to extract active substances and identify the levels of antimicrobial active substances. The TLC Spectrophotodensitometer instrument and the diffusion method (discs) were used to test antimicrobial potential. The Trueexperimental method with Posttest only-control design was used in this study, by intervening in the treatment group as well as the presence of positive and negative controls. Data analysis began with the Kolmogorov Smirnov test, then One Way ANOVA (Analysis of Variance) test was used to determine the inhibition zone of various types of traditional Balinese spices extract, then compared to the NCCLS table (National Committee for Clinical Laboratory Standards) to determine the most potential types of traditional Balinese spices as antimicrobials against the growth of Salmonella sp.

\section{RESULTS AND DISCUSSION}

The results of qualitative tests by phytochemical screening on the content of antibacterial compounds of traditional Balinese spices obtained the following results (Table 1). 
Table 1. Qualitative Test Results of Antibacterial Compounds from Traditional Balinese Spices Extracts No Spices Samples Antibacterial Compounds Test Results

\begin{tabular}{llccccc}
\cline { 3 - 6 } & & Alkaloids & Saponin & Phenol & Flavonoids & Tannins \\
\hline 1 & Basa Wangen & + & - & + & + & + \\
2 & Basa Gede & + & - & + & + & + \\
3 & Basa Bawang Jahe & + & - & + & + & + \\
4 & Basa Selem & - & - & + & + & + \\
5 & Basa Rajang & - & - & + & + & + \\
\hline
\end{tabular}

Noted: (+) detected; (-) not detected

Qualitative test results indicate there is a positive compound; it is suspected that the compound has antibacterial activity (phenol, flavonoid, and tannin compounds). Quantitative tests were continued to determine the levels of compounds suspected to have antibacterial activity (total phenols, flavonoids and tannins) (table 2).

Table 2. Quantitative Test Results of Traditional Balinese Spices Extracts Antibacterial Compounds

\begin{tabular}{llccc}
\hline No & Spices Samples & \multicolumn{3}{c}{ Antibacterial Compounds } \\
\cline { 3 - 5 } & & Phenol (mg/mL.GAE) & Flavonoids $(\mathrm{mg} / \mathrm{mL}$. RE) & Tannins mg/mL.GAE) \\
\hline 1 & Basa Wangen & 3.39 & 3.27 & 6.66 \\
2 & Basa Gede & 1.83 & 3.74 & 1.35 \\
3 & Basa Bawang Jahe & 2.14 & 2.46 & 2.49 \\
4 & Basa Selem & 2.42 & 1.96 & 2.87 \\
5 & Basa Rajang & 3.35 & 6.96 & 2.35 \\
\hline
\end{tabular}

Noted: GAE: Gallic Acid Equivalents; RE: Rutin Equivalents

In this study, the inhibitory test of Balinese traditional spices concentrations of $100 \%(1 \mathrm{mg} / \mathrm{ml})$ was carried out on the growth of Salmonella sp. bacteria using $96 \% \mathrm{EtOH}$ as a negative control and Ciprofloxacin $5 \mu \mathrm{g}$ as a positive control. The positive control showed a zone of inhibition until the eighth replication. The positive zone inhibition zone values obtained were not very different. The mean inhibition zone diameter obtained was $31.88 \mathrm{~mm}$ (Table 3).

Table 3. Inhibition Zone of Traditional Balinese Spices on the growth of Salmonella sp. in Vitro

\begin{tabular}{|c|c|c|c|c|c|c|c|}
\hline \multirow[t]{2}{*}{ Replications } & \multicolumn{7}{|c|}{ Inhibition zone } \\
\hline & $\begin{array}{c}\text { Basa Selem (1 } \\
\mathrm{mg} / \mathrm{ml})\end{array}$ & $\begin{array}{c}\text { Basa Gede } \\
(1 \mathrm{mg} / \mathrm{ml})\end{array}$ & $\begin{array}{c}\text { Basa } \\
\text { Wangen (1 } \\
\mathrm{mg} / \mathrm{ml})\end{array}$ & $\begin{array}{c}\text { Basa Bawang } \\
\text { Jahe (1 } \\
\mathrm{mg} / \mathrm{ml})\end{array}$ & $\begin{array}{c}\text { Basa } \\
\text { Rajang (1 } \\
\text { mg/ml) }\end{array}$ & $\begin{array}{l}\text { Positive } \\
\text { control }\end{array}$ & $\begin{array}{l}\text { Negative } \\
\text { control }\end{array}$ \\
\hline 1 & 20 & 20 & 21 & 17 & 22 & 32 & 0 \\
\hline 2 & 15 & 21 & 18 & 18 & 19 & 31 & 0 \\
\hline 3 & 20 & 19 & 19 & 17 & 17 & 33 & 0 \\
\hline 4 & 14 & 18 & 16 & 15 & 19 & 32 & 0 \\
\hline 5 & 15 & 21 & 16 & 15 & 18 & 34 & 0 \\
\hline 6 & 18 & 19 & 18 & 19 & 18 & 30 & 0 \\
\hline 7 & 16 & 18 & 21 & 19 & 19 & 32 & 0 \\
\hline 8 & 19 & 20 & 19 & 18 & 21 & 31 & 0 \\
\hline Mean \pm SD & $17.13 \pm 2.42$ & $19.5 \pm 1.19$ & $18.5 \pm 1.92$ & $17.25 \pm 1.58$ & $19.13 \pm 1.57$ & $\begin{array}{c}31.88 \pm \\
1.25\end{array}$ & $0.0 \quad 0.00$ \\
\hline
\end{tabular}

Noted: SD: Standard Deviation

The mean diameter of negative controls showed there was none inhibitory activity of Salmonella $s p$. bacteria growth, starting from replication one to replication eight, the inhibition zone diameter of negative control obtained was $0 \mathrm{~mm}$. 


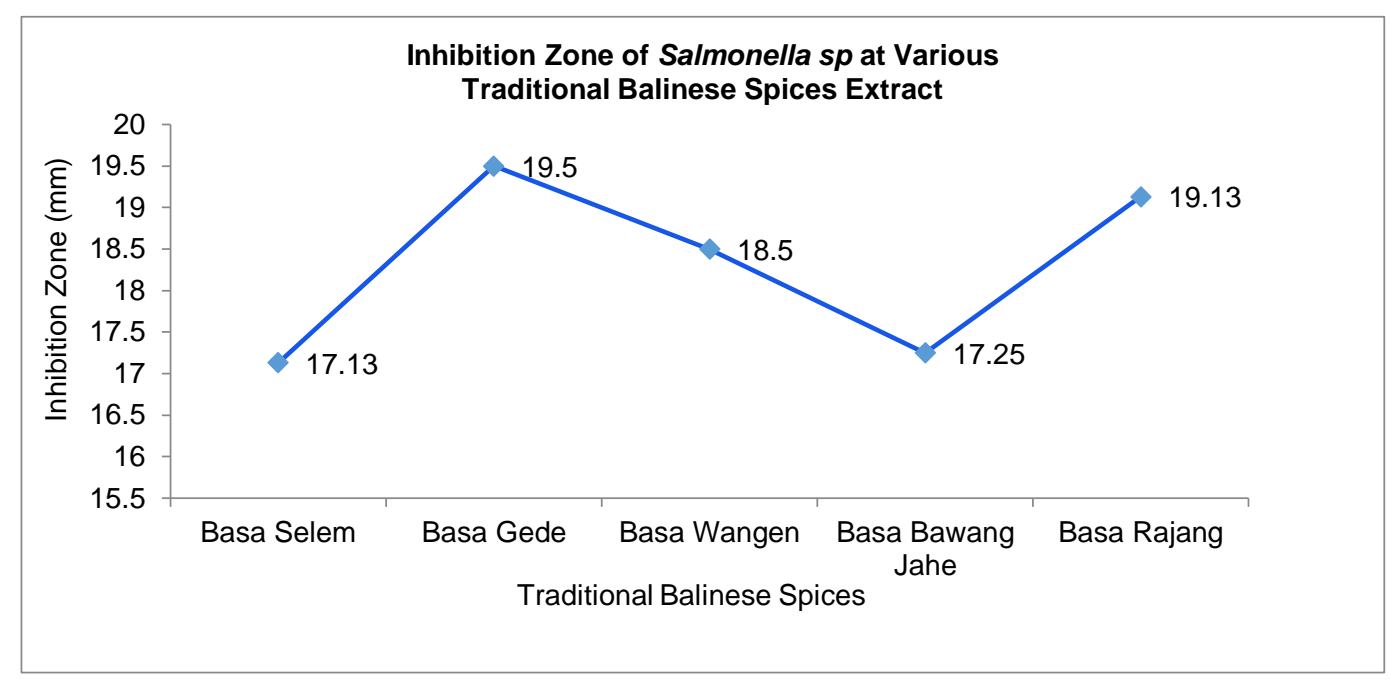

Figure 1. Inhibition Zone Differences of Various Traditional Balinese Spices Extract

Based on the results of the current study, none of the traditional Balinese spices was effective against the growth of Salmonella $s p$ (when compared to the NCCLS table). Inhibitory zone diameters formed in various traditional Balinese spices are in the intermediate category (16$20 \mathrm{~mm}$ ). One Way ANOVA test results (using software SPSS 16.00) obtained sig value was 0.037 $(<0.05)$. The results showed there was a differences inhibition zone of Salmonella $s p$ in various Balinese traditional spices with concentration $1 \mathrm{mg} / \mathrm{ml}$. Based on these results, there are differences in the antimicrobial potential of various types of traditional Balinese spices extracts against Salmonella sp. The differences in inhibitory activity from various types of traditional Balinese spices extracts was analyzed by LSD (Least Significant Difference) test. The LSD test showed that $p$-value was $0.000(p<\alpha)$; there were significant differences in the effectiveness of biodesinfectant at various traditional Balinese spices extracts against Salmonella sp.

The inhibitory test was conducted to determine the antibacterial potential of traditional Balinese spices against Salmonella sp. bacteria. Traditional Balinese spices extract was obtained through the maceration method using $96 \% \mathrm{EtOH}$, and the extract obtained then tested for its inhibitory activity. Based on the results of the observation, all the various traditional Balinese spices extract have inhibition on the growth of Salmonella sp. bacteria. Inhibition can be seen from the clear zones that formed around the disk containing traditional Balinese spices extract. In this method, the extract on the disk will diffuse, and the active substances contained in it will inhibit bacterial growth. The wider the clear zone formed shows, the more significant inhibitory activity. In this study, $96 \%$ ethanol was used as a negative control to determine whether there is an effect of ethanol on the growth of Salmonella sp. bacteria which is also used as a solvent in the extraction process. The mean diameter of negative controls showed there is no inhibitory activity of Salmonella sp. bacteria growth with a measured value of $0.00 \mathrm{~mm}$. The same thing was also obtained from the study in vitro inhibitory activity of ethanolic fruit extract from Averrhoa bilimbi L. against Streptococcus pyogenes bacteria. $\frac{5}{}$

In this study, the positive controls used Ciprofloxacin antibiotic discs as work controls. Ciprofloxacin is a broad-spectrum antibiotic that is widely used to treat human and animal diseases, which Ciprofloxacin is a broad-spectrum antibiotic of the fluoroquinolone class. Ciprofloxacin is active against some Gram-positive and many Gram-negative bacteria. Ciprofloxacin has rapidly bactericidal activity and high potency. Relatively long post-antibiotic effect. .5 The mean diameter of the inhibition zone from Ciprofloxacin antibiotic discs was 31.88 $\mathrm{mm}$. These results are according to CLSI (Clinical and Laboratory Standards Institute), where 
Ciprofloxacin belongs to the sensitive category. It is indicated that the bacterial isolates used and the procedures carried out in this study are confirmed with testing standards for inhibiting antibacterial substances. $\underline{6}$ This study also shows that Ciprofloxacin is still effective against Salmonella sp. bacteria. ${ }^{?}$

The results of this study show that traditional Balinese spices extract $(1 \mathrm{mg} / \mathrm{ml})$ were able to inhibit the growth of Salmonella sp. Bacteria which was characterized by the formation of clear zones around the discs. This study also shows that different diameter inhibition zones are formed for each traditional Balinese spices extract. It might be caused the differences of spices content and the number of spice compositions (which contain antimicrobial compounds) in traditional Balinese spices. The result of the largest inhibition zone was produced by Basa Gede, which was equal to $19.50 \mathrm{~mm}$, among the other traditional Balinese spices. It might be caused the Basa Gede consists of spice components that are more complete than other spices. Basa Gede contains galangal, ginger, turmeric, shallots, garlic, pepper, coriander, chilli, cumin leaves, bay leaves, Wangen leaves, and lemongrass. The beneficial properties in herbs and spices are due to the presence of phytochemicals. The major phytochemical classes associated with herbs and spices include a diverse array of compounds such as terpenes and terpene derivatives. ${ }^{8}$ Other compounds include glycosides, alkaloids like piperine, chavicene, capsaicinoids (pepper fruit), saponins like trigonelline, allyl sulphur, adenosine, (onions and garlic), quercetin (onions), curcumin (turmeric) and isothiocyanates (cruciferous vegetables). 9 Qualitative test results by phytochemical screening indicate the presence of alkaloids, flavonoids, phenols, and tannins contained in the extract. Flavonoid is an active substance which is a class of hesperidin compounds and causes damage to bacterial cell wall permeability, microsomes, and lysosomes as a result of interactions between flavonoids and bacterial DNA. $\frac{10}{}$

Phenol is one of the compounds contained in essential oils which has a broad spectrum of bioactivity, owing to the presence of several active ingredients or secondary metabolites, which work through various modes of action. $\frac{11}{}$ Essential oils contain a variety of volatile molecules such

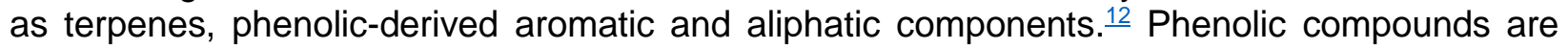
generally claimed to be bacteriostatic. Moreover, the antimicrobial action of phenols is related to their ability to denature proteins, as well as to produce a loss of membrane integrity resulting in leakage of essential intracellular constituents such as potassium cation, inorganic phosphate, pentoses, nucleotides and nucleosides, and proteins. The mechanisms thought to be responsible for phenolic toxicity to microorganisms include enzyme inhibition by the oxidized compounds, possibly through reaction with sulfhydryl groups or through more non-specific interactions with the proteins. $\frac{13}{1 a n n i}$

Tannins (commonly referred to as tannic acid) are water-soluble polyphenols that are present in many plant foods. Tannin toxicity for fungi, bacteria and yeasts is reviewed and compared to the toxicity of related lower molecular weight phenols. The dependence of toxicity on tannin structure is examined. $\frac{14}{1}$ The different mechanisms proposed so far to explain tannin antimicrobial activity include inhibition of extracellular microbial enzymes, deprivation of the substrates required for microbial growth or direct action on microbial metabolism through inhibition of oxidative phosphorylation. $\frac{15}{}$

The formation of different inhibitory zones due to variations in the types of constituent variations and differences in the number of components and storage conditions. 11 The freshness index of the ingredients of traditional Balinese spices can be seen from the texture of the material, the overall colour of the material, the basic colour of the skin, the colour of the contents of the material, the hardness (firmness) of the material, the content of dissolved sugar (solid soluble content), acidity, and the concentration of ethylene. Harvesting of traditional Balinese spices ingredients which is done earlier or rather late can affect the quality of spices, such as colour, texture, taste and aroma as well as the content of chemical compounds especially those that are harvested earlier or later. This influences changes in chemical and physical properties during 
maturation because after harvesting the material still performs metabolic reactions. The optimum temperature for storing materials is $5-10^{\circ} \mathrm{C}$. If the temperature is too low, it can cause damage to the material (chilling injury). Other factors that affect the inhibition zone diameter are the incubation temperature, incubation time, tool sterility, contamination, the turbidity of the bacterial

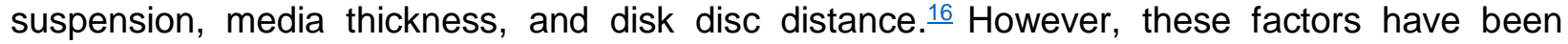
controlled, so these factors do not have a significant influence on the results of this study.

This research can be continued by using modifying formulas from traditional Balinese spices, so the concentration of antimicrobial compounds contained becomes higher. This is expected to increase the inhibitory growth of Salmonella sp. bacteria.

\section{CONCLUSION}

Based on the results of the research, it can be concluded that the traditional Balinese spices contain antibacterial compounds such as flavonoids, alkaloids, phenols $(3.35 \mathrm{mg} / \mathrm{ml})$ and flavonoids $(6.96 \mathrm{mg} / \mathrm{ml})$ and tannin $(6.66 \mathrm{mg} / \mathrm{ml})$ with antimicrobial potential categories was intermediate (inhibitory range was $16-20 \mathrm{~mm}$ ). There are differences in the antimicrobial potential of various types of traditional Balinese spices against the growth of Salmonella sp. bacteria in vitro with sig value was $0.037(<0.05)$. The result of the largest inhibition zone was produced by Basa Gede, which was equal to $19.50 \mathrm{~mm}$, among the other traditional Balinese spices.

\section{DISCLOSURE STATEMENT}

The authors reported no potential conflict of interest.

\section{ACKNOWLEDGEMENT}

Researchers thanks to all team and to Directure of Poltekkes Kemenkes Denpasar.

\section{FUNDING INFORMATION}

This research was funded by the RISBINAKES fund (research for the development of health personnel) of the DIPA Poltekkes Denpasar.

\section{REFERENCES}

1. Rahayu NPN, Kawuri R, Suriani NL. Uji Keberadaan Staphylococcus aureus pada Sosis Tradisional (Urutan) yang Beredar di Pasar Tradisional di Denpasar, Bali. Simbiosis J Biol Sci. 2014;2(1).

2. Billing J, Sherman PW. Antimicrobial Functions of Spices: Why Some Like it Hot. Q Rev Biol. 1998;73(1):3-49. doi:10.1086/420058.

3. Antara NS, Wartini M. Senyawa Aroma Dan Citarasa ( Aroma and Flavor Compounds ). Trop Plant Curric Proj. 2016;(October):1-71.

4. Hanafiah KA. Rancangan Percobaan Aplikatif. Jakarta: PT. RajaGrafindo Persada; 2005.

5. Dewi P, Ratih GA, Burhannuddin B, Sudarmanto G. In vitro Inhibitory Activity of Ethanolic Fruit Extract from Averrhoa bilimbi L. against Streptococcus pyogenes Bacteria. Heal Notions. 2019;3(1):13-17. doi:10.33846/hn.v3i1.276.

6. CLSI. M100 Performance Standards for Antimicrobial Susceptibility testing. In: Megan L, M. Tertel, eds. 27th ed. West Valley Road USA; 2017.

7. Zeiler HJ, Grohe K. Summary for Policymakers. In: Intergovernmental Panel on Climate Change, ed. Climate Change 2013 - The Physical Science Basis. Vol 1. Cambridge: Cambridge University Press; 1986:1-30. doi:10.1017/CBO9781107415324.004.

8. Lampe JW. Spicing up a vegetarian diet: chemopreventive effects of phytochemicals. Am J Clin Nutr. 2003;78(3):579S-583S. doi:10.1093/ajen/78.3.579S.

9. Keservani RK, Kesharwani RK, Vyas N, Jain S, Raghuvanshi R, Sharma AK. Nutraceutical and Functional Food As Future Food: A Review. Der Pharm Lett. 2010;2(1):106-116. 
10. Rijayanti RP, Luliana S, Trianto HF. In vitro Antibacterial Activity test Of Ethanol Extracts Bacang mango (Mangifera foetida L.) Leaves Against Staphylococcus aureus. Naskah Publ Univ Tanjungpura. 2014;1(1):10-12.

11. Abad MJ, Bedoya LM, Apaza L, Bermejo P. The Artemisia L. Genus: A Review of Bioactive Essential Oils. Molecules. 2012;17(3):2542-2566. doi:10.3390/molecules17032542.

12. Blagojević $P$, Radulović N, Palić R, Stojanović G. Chemical Composition of the Essential Oils of Serbian Wild-Growing Artemisia absinthium and Artemisia vulgaris. J Agric Food Chem. 2006;54(13):4780-4789. doi:10.1021/jf060123o.

13. Furneri PM, Bisignano G. Usage of Hydroxytyrosol for Antimycoplasmal Activity. In: Preedy VR, Watson RR, eds. Olives and Olive Oil in Health and Disease Prevention. Elsevier; 2010:1283-1288. doi:10.1016/B978-0-12-374420-3.00142-X.

14. Scalbert A. Antimicrobial properties of tannins. Phytochemistry. 1991;30(12):3875-3883. doi:10.1016/0031-9422(91)83426-L.

15. Chung K-T, Wong TY, Wei C-I, Huang Y-W, Lin Y. Tannins and Human Health: A Review. Crit Rev Food Sci Nutr. 1998;38(6):421-464. doi:10.1080/10408699891274273.

16. Keskin D, Toroglu S. Studies on antimicrobial activities of solvent extracts of different $\begin{array}{llll}\text { spices. } & J & \text { Bnviron } & \text { 2011;32(2):251-256. }\end{array}$

http://www.ncbi.nlm.nih.gov/pubmed/21882663.

\section{SHORT BIOGRAPHY}

\section{Nyoman Jirna}

Does research in Microbiology. Current research interest include identification of Aspergillus species in Tumeric Jamu. https://scholar.google.co.id/citations?user=YzOjKmkAAAAJ\&hl=en 